Data としては

A) A. Causen,W E. S. Turner, J. Soc. Glass Tech., 12, 169, 1928; 3, 238, 1919; 4, 115, $1920 ; 5,121,1921 ; 5,183,1921$

B) S. English W. E. S. Turner, J. Soc. Glass Tech.,

C) R. Wenig. E. Zschimmer, Sprechsaal, 62, 855, 874, 889, 1929

D) G. Gehlhoff. M. Thomas, Lehrbuch. tech.
Phys., 3, 756

E) E. J. Gooding. W. E. S. Turner, J. Soc. Gass Tech., 18, 32, 1934

F) 交中2) 安部俊夫, 穼協, 12月, 昭和25年 2) 化學的耐久性に關乙て注

A) V. Dimbleby. M. Parkin and W. E. S. Turner1) 文中, J. Soc. Glas. Tech., 13, 248, 1929

\title{
嗍珪酸ガラスの構造
}

安 部 俊夫

(東京芝浦電氣株式會补:マッダ研究所)

\section{The Structure of Borosilicate Glasses}

\author{
By Tosio ABE
}

In the author's previous paper, it was stated that due to the disposition that the cations of the modifying oxide do not approach to each other, atomic groups denominated as $\mathrm{xy}_{4}$ are formed in glasses containing $\mathrm{B}_{2} \mathrm{O}_{3}$ at the viscosity of about $1.5 \times 10^{12}$ poises, i.e., near the contraction temperature of the glass. In this paper, further considerations concerning the $\mathrm{xy}_{\mathrm{t}}$-group formation in borosilicate glasses are given from the point of view of the ionic refraction of various oxygens in sodium borate glasses.

It is deduced that the $\mathrm{B}-\mathrm{O}$ bonds in the $\mathrm{BO}_{4}$ tetrahedron which is located in the central part of the $\mathrm{xy}_{4}$-group is very strong, and this tetrahedron is formed at the expense of the loosening of the $\mathrm{B}-\mathrm{O}$ bonds in the $\mathrm{BO}_{3}$ triangles around it, i.e., these $\mathrm{BO}_{3}$ triangles are unstable in comparison with those in the normal state. Accordingly, the predominance in rumber of the atomic groups $\mathrm{xy}_{4}$ in comparison with other groups such as $\mathrm{xy}_{3} z, \mathrm{xy}_{2} z_{2}, \mathrm{xyz}_{3}$, or $\mathrm{xz}_{4}$, where $\mathrm{x}, \mathrm{y}$, and $\mathrm{z}$ represent $\mathrm{BO}_{4}$ tetrahedron, $\mathrm{BO}_{3}$ triangle and $\mathrm{SiO}_{4}$ tetrahedron, respectively, is explained.

When the $\mathrm{Na}_{2} \mathrm{O}$ content in the sodium borate glass is increased above 0.167 , Na ions begin to cut the $\mathrm{E}-\mathrm{O}$ bonds around $\mathrm{xy}_{4}$-groups, and as the result, the unstable $\mathrm{BO}_{3}$ triangles around $\mathrm{BO}_{4}$ tetrahedron must be stabilized to some degree. It may be supposed that these $\mathrm{Na}$ ions should then be trapped in deep potential holes on cutting off the $\mathrm{B}-\mathrm{O}$ bonds. These $\mathrm{Na}$ ions should not be so free as those added later, and they may be regarded as the so-called "enclosed" $\mathrm{Na}$ ions.

It may also be supposed that for each one $\mathrm{xy}_{+}$-group, one $\mathrm{Na}$ ion could be the "enclosed" ion, i.e., free $\mathrm{Na}$ ions should begin to be produced at the composition $2 \mathrm{Na}_{2} \mathrm{O} \cdot 5 \mathrm{~B}_{2} \mathrm{O}_{3}$ or 28.6 mol\% $\mathrm{Na}_{2} \mathrm{O}$. Thus the location of the maximum transition temperature curve in the ternary diagram $\mathrm{Na}_{2} \mathrm{O}-\mathrm{B}_{2} \mathrm{O}_{3}-\mathrm{SiO}_{2}$, and the stability of the network of borosilicate glasses are discussed.

\section{I. 緒 言}

著者は前に(1) $\mathrm{B}_{2} \mathrm{O}_{3}$ を含有するガラス中では修飾酸 化物の陽イオンが互に近接し難いことに基き粘度 1.5 $\times 10^{12}$ poises の附近, 即ちガラス屈伏點に近い温度 で $\mathrm{BO}_{4}$ 四面體の角頂を共有して 4 ケの $\mathrm{BO}_{3}$ 三角 形がつながつている $\mathrm{xy}_{4}$ と名づけられる原子集團
が形成せられること，この原子集團の形成によつてが ラスの熱膨脹係數は小となり,一方 $\mathrm{SiO}_{2}$ と $\mathrm{B}_{2} \mathrm{O}_{3}$ と の分子比が 3 ：2 より大きいガラスでは，この集團の 形成に伴つてガラスが必然的に $\mathrm{SiO}_{2}$ にさ部分と， $\mathrm{Na}_{2} \mathrm{O}$ と $\mathrm{B}_{2} \mathrm{O}_{3}$ とにとむ部分との 2 相に分離し, その ためにガラスの轉移點は下降し屈伏點は上昇すること 
及びガラス中に多原子價の修飾酸化物が存在するとき はその陽イオンによつていくつかの $\mathrm{xy}_{4}$ 群が集めら れるために分離相は大きくなり，この樣にして生じた $\mathrm{SiO}_{2}$ にとむ相に扔けるクリストバライトの微結晶の 析出によつてガラス全體が乳白化すること等について 述べ，更にガラス中に含有される少量の $\mathrm{Al}_{2} \mathrm{O}_{3}$ の存 在がかつる原子集團の形成を妨げることについても明 かにしたのであるが，本論文に扔いては既に注意深く 測定されている硯酸ナトリウムガラスの比重及び屈折 率の值に基いてこの $\mathrm{xy}_{4}$ 群の形成について更に細か な考察を進めることつする。

\section{II. 磞酸ナトリウムガラスの比重と屈折率 及びそれから計算した分子屈折}

研酸ナトリウムガラスの比重及び屈折率の值は徐冷 したガラスについては Gooding 及び Turner(2), Wulff 及び Majumdar(3), Morey 及び Merwin(4), Tillotson(5), Bedson 及び Williams ${ }^{(6)}$ 等の測定值が むり，この他に測定值が小數點以下 2 桁までである がStevels(7) の測つた比重の值もある。第1表にこれ らの值を示す。測定者の $\mathrm{G}, \mathrm{W}, \mathrm{M}, \mathrm{T}, \mathrm{B}$, 及び $\mathrm{S}$ 等はそれぞれ上記の測定者を示す。

第 1 表 徐冷された碵酸ナトリウム ガラスの比重及び屈折率

\begin{tabular}{|c|c|c|c|c|c|}
\hline \multicolumn{2}{|c|}{ 組成(wt\%) } & 比重 & 屈折率 & 测定 & \multirow{2}{*}{ 註 } \\
\hline $\mathrm{Na}_{2} \mathrm{O}$ & $\mathrm{B}_{2} \mathrm{O}_{3}$ & $\mathrm{~d}$ & $\mathrm{n}_{\mathrm{D}}$ & 者 & \\
\hline 0 & 100 & 1.812 & 1.4582 & W & \\
\hline 2.36 & 97.66 & 1.8662 & & G & \\
\hline 3.38 & 96.56 & 1.8632 & & $\mathrm{G}$ & \\
\hline 6.84 & & 1.9876 & 1.4841 & $\mathrm{~W}$ & \\
\hline 7.78 & 92.18 & 1.9367 & & G & \\
\hline 11.43 & 88.56 & 2.0631 & & $\mathrm{G}$ & \\
\hline 13.76 & 86.28 & 2.1285 & & G & \\
\hline 15.80 & 84.22 & 2.1369 & & $\mathrm{G}$ & \\
\hline & 81.79 & & 1.501 & M & $\mathrm{Na}_{2} \mathrm{O} \cdot 4 \mathrm{~B}_{2} \mathrm{O}_{3}$ ガラス \\
\hline .18 .46 & 81.47 & 2.2309 & & $\mathrm{G}$ & \\
\hline 21.76 & 78.19 & 2.2486 & & $\mathrm{G}$ & \\
\hline 30.18 & $69 \cdot 88$ & 2.3703 & & $\mathrm{G}$ & \\
\hline 30.7 & 69.3 & 2.370 & & $\mathrm{~T}$ & $\mathrm{Na}_{2} \mathrm{O} \cdot 2 \mathrm{~B}_{2} \mathrm{O}_{3}$ ガラス \\
\hline$(30.8)$ & & & 1.515 & B & " " " \\
\hline & 69.14 & & 1.516 & M & "I \\
\hline 6.2 & 93.8 & 1.92 & & $\mathrm{~S}$ & \\
\hline 10.0 & 80.0 & 2.02 & & S & \\
\hline 16.2 & 83.8 & 2.16 & & S & \\
\hline 20.0 & $80 \cdot 0$ & 2.23 & & S & \\
\hline 30.0 & 70.0 & 2.36 & & $\mathrm{~S}$ & \\
\hline
\end{tabular}

これらの値をwt\%の組成に對して圖に表わすと第1 圖の樣になり比較的なめらかな曲線に沿つていること がわかる。圖中の各測定點につけた文字はそれぞれの
測定者を表す。この比重及び屈折率曲線から Na.20 wt \% が 5，10，15，20，25，30 の各組成に對する比 重及び屈折率を求め，それからガラスの分子屈折を計 算すると第 2 表の值が得られた。

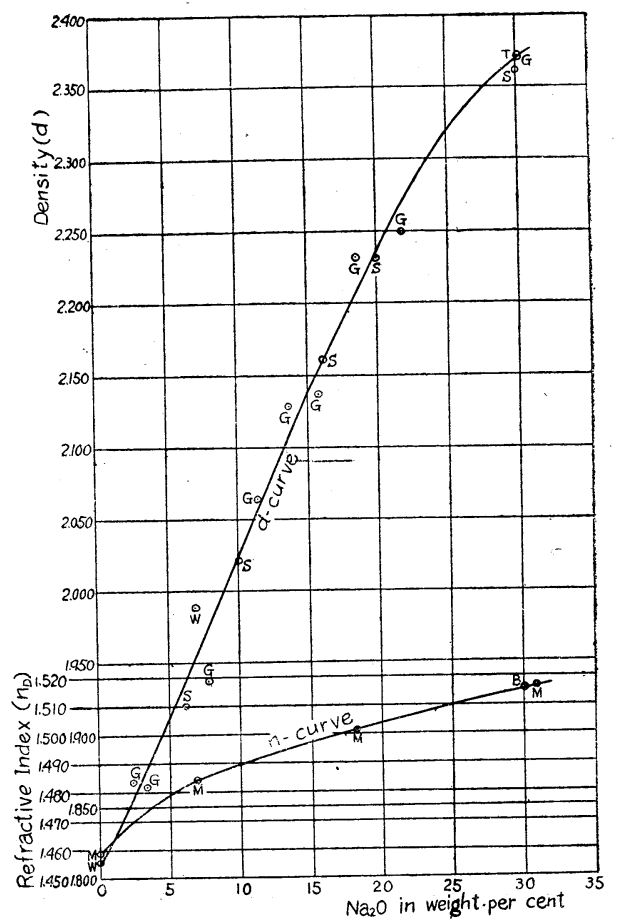

Fig. 1. Density and refractive index of glasses in the binary system $\mathrm{Na}_{2} \mathrm{O}-\mathrm{B}_{2} \mathrm{O}_{3}$, as determined by several observers.

等 2 表 徐冷された硼酸ナトリウムガラスの 比重, 屈折率及び分子屈折

$\begin{array}{ccccc}\begin{array}{c}\text { 組 } \\ w t \% \mathrm{Na}_{2} \mathrm{O}\end{array} & \begin{array}{c}\text { 成 } \\ \mathrm{mol} \% \mathrm{Na}_{2} \mathrm{O}\end{array} & \begin{array}{c}\text { 比重 } \\ \mathrm{d}\end{array} & \begin{array}{c}\text { 屈折率 } \\ \mathrm{n}_{\mathrm{D}}\end{array} & \begin{array}{c}\text { 分子屈折 } \\ \mathrm{R}\end{array} \\ 0 & 0 & 1.812 & 1.458 & 10.488 \\ 5 & 5.61 & 1.912 & 1.479 & 10.266 \\ 10 & 11.08 & 2.024 & 1.489 & 9.809 \\ 15 & 16.54 & 2.140 & 1.4965 & 9.342 \\ 20 & 21.94 & 2.237 & 1.503 \overline{3} & 8.990 \\ 25 & 27.23 & 2.318 & 1.510 & 8.717 \\ 30 & 32.51 & 2.369 & 1.515 & 8.546\end{array}$

次に急冷したガラスについては Wulff 及び Majumdar (3) が9 種のガラスについて比重及び屈折 率を測つている。この場合は比重及び属折率が同一の ガラスについて求められているので，分子屈折はそれ ぞれのガラスに對して直接求めることができ，第 3 表 に示す值が得られた。

これらの分子屈折の值はすべてガラスの分子量 $\mathrm{M}_{\mathrm{g}}$ として $\mathrm{M}_{\mathrm{g}}=u \mathrm{M}_{\mathrm{Na}_{2} \mathrm{O}}+(1-u) \mathrm{MsiO}_{2} \ldots \ldots . . . .(1)$ をとり 
第 3 表 急冷された嗍酸ナトリウムガラスの 比重, 佣折率及び分子屈折 (Wulff 及び Majụmdar による)

\begin{tabular}{|c|c|c|c|c|}
\hline $\begin{array}{c}\text { 組 } \\
w t \% \mathrm{Na}_{2} \mathrm{O}\end{array}$ & $\stackrel{\text { 成 }}{\mathrm{mol} \% \mathrm{Na}_{2} \mathrm{O}}$ & $\begin{array}{c}\text { 比重 } \\
\mathrm{d}\end{array}$ & $\begin{array}{c}\text { 蟨折率 } \\
\mathrm{n}_{\mathrm{D}}\end{array}$ & $\begin{array}{c}\text { 分子屈折 } \\
\mathrm{R}\end{array}$ \\
\hline 0 & 0 & 1.778 & 1.4502 & 10.528 \\
\hline 6.84 & 7.62 & 1.9690 & 1.4797 & 9.957 \\
\hline 9.15 & 10.16 & 2.0090 & 1. 4839 & 9.807 \\
\hline $16.51 \mathrm{a}$ & 18.18 & 2.1226 & 1.4953 & 9.382 \\
\hline $16.51 \mathrm{~b}$ & 18.18 & 2.1235 & 1. 4958 & 9.385 \\
\hline 23.19 & 25.33 & 2.2303 & 1.5051 & 9.004 \\
\hline 28.28 & 30.70 & 2.3285 & 1.5136 & 8.696 \\
\hline $28.41 \mathrm{a}$. & 30.83 & 2.3322 & 1.5144 & 8.692 \\
\hline $28.41 \mathrm{~b}$ & 30.83 & 2.3324 & 1.5147 & 8.694 \\
\hline
\end{tabular}

Lorentz-Lorenz の式によつて計算した。但し u は $\mathrm{Na}_{2} \mathrm{O}$ の分子率, $\mathrm{M}_{\mathrm{Na}_{2} \mathrm{O}}$ 及文び $\mathrm{M}_{\mathrm{SiO}_{2}}$ はそれぞれ $\mathrm{Na}_{2} \mathrm{O}$ 及び $\mathrm{SiO}_{2}$ の分子量である。これらの值を $\mathrm{Na}_{2} \mathrm{O}$ の mol\% に對して描くと第 2 圖の曲線とな り，徐冷したガラスと急冷しだガラスとでは曲線の樣 子に著しい差異があることがわかる。

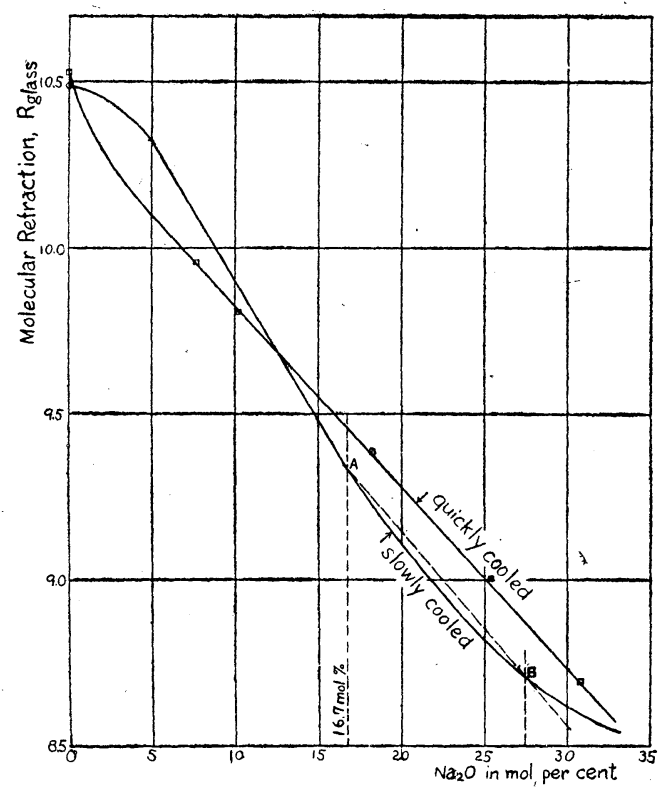

Fig. 2. Molecular refraction of giasses in the binary system $\mathrm{Na}_{2} \mathrm{O}-\mathrm{B}_{2} \mathrm{O}_{3}$.

III. 淜酸ナトリウムガラスにおける $\mathrm{xy}_{4}$ 群の形成 軟化温度よりあまり高くない温度に扎ける硼酸ナト リウムガラスの構造は著者の前論文(1)に述べた種々の 實驗結果に基いて想像与ることができる。その最す簡 單な圖は常温における構造圖(8)と大差はないが，すべ そのB原子が 3 ケのO原子によつて圍まれようとし，
B-O 網目のすき間に入つて不規則に存在している $\mathrm{Na}$ イオンが常温よりあずつと動きやすい狀態にある ことが異つている。

この樣な狀態に扎いては Naイオンのむるすのは通 例の場合の樣に B-O 結合を切斷する代りにある瞬間 に扔いては $\mathrm{BO}_{3}$ 三角形の上に接しその 3 ケの $\mathrm{O} に$ 均等につながることもあると考えられる。か子る場合 には三つの B-O 結合は同樣に弱まり，B原子は不飽 和となるために $\mathrm{BO}_{3}$ 三角形の反對側に更に1 ケの不 飽和酸素を引きつけその結果として $\mathrm{BO}_{4}$ が形成せら れる。か〉る $\mathrm{BO}_{4}$ 四面體は明かにその周邊に $\mathrm{Na}$ イオンの占める位置としてルつの等價な場所を有して いる。そしてこれらの場所相互間のポテンシャル障壁 はあまり高くない上 $\mathrm{Na}$ イオンはか〉る高温度では 著しく動き易いため，これらの四つの場所の間をかな り自由に動きまわり，これらの 4 ケの不飽和酸素を均 等に中和主ると考えられる。これと同時にこの $\mathrm{Na}$ イオンは他の Na イオンが近づくのを妨げるために 前論文に述べた $\mathrm{xy}_{4}$ 群が形成されるのである。

上述の想像に對し, 今もし $\mathrm{Na}$ イオンがこれらの凹 つの場所の間を動きまわることが出來ないとすれば, Na イオンはそれに面している3 ケのOだけを中和す ること〉なり, 反對側の 1 ケのはこの Naイオンの 影響をうけないからその結果として $\mathrm{y}_{3} \mathrm{xxy}_{3}$ といら樣 な原子集團の形成が可能となる。しかし，この樣な原 子集團が形成されるならば, $\mathrm{Na}_{2} \mathrm{O}-\mathrm{B}_{2} \mathrm{O}_{3}$ 系ガラスに おける膨脹係數の極小值は實驗的に確められている $\mathrm{Na}_{2} \mathrm{O} \cdot 5 \mathrm{~B}_{2} \mathrm{O}_{3}$ 以外の組成，例えば上記の原子集團が最 も形成され易い條件の下では丁度 $\mathrm{Na}_{2} \mathrm{O} \cdot 8 \mathrm{~B}_{2} \mathrm{O}_{3}$ 即ち $\mathrm{Na}_{2} \mathrm{O} 11.1 \mathrm{~mol} \%$ の所で見出される筈である。しかし 實際上は $\mathrm{Na}_{2} \mathrm{O} \cdot 5 \mathrm{~B}_{2} \mathrm{O}_{3}$ に最小值が見出されるから上 に述べた想像は支持されてよいであろう。しかしガ ラスの温度が低くなると妸論ある温度以下では Na イ オンの可動性は小さく，その反對側の○に影響を及㴗 すことが出來なくなる筈であるが，か〉る場合には酸 素の可動性はずつと小さくなり, 新しい原子集團の形 成即ち原子の配列の變更は不可能である。

上に述べた樣にして $\mathrm{xy}_{4}$ 群が形成されるためには ガラスの温度はある脄い範圍に限定される筈である。 即ち原子の配列の變更ができる程度にガラスの粘度は 小さくなければならぬが，そのために温度は充分高い ことが必要である。また同時に一方では Naイオンが $\mathrm{BO}_{4}$ 四面體が形成される以前に熱振動によつて $\mathrm{BO}_{3}$ 
三牦形の 3 ケの○から離れることがないために温度は ある程度低くなければならぬ。即ち $\mathrm{xy}_{4}$ 群形成の條 件の一つとして，ガラスは上記の樣な適當な温度に充 分長く保持されることが必要である。

第 3 圖に硯酸ナトリウムガラスを構成する種々の原 子に對して任意につけな記號を示す。即ち徐冷したガ ラスは $\mathrm{B}, \mathrm{Na}, \mathrm{O}^{\mathrm{BIII}}, \mathrm{O}^{\mathrm{BIV}}$ 及び $\mathrm{O}^{\mathrm{Na}}$ より成り, 急 冷したガラスは $\mathrm{B}, \mathrm{Na}, \mathrm{O}^{\mathrm{BIII}}$ 及び ONa で棈成され る。徐冷ガラスに對しては ONa は u が 0.167 以上 ではじめて存在する。

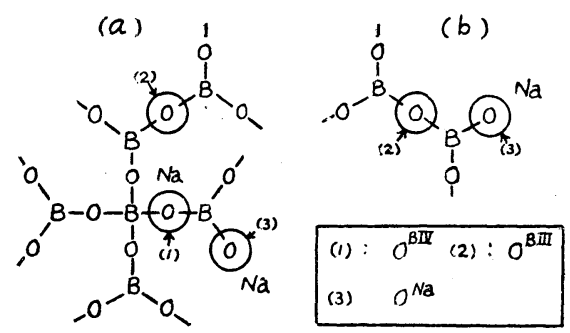

Fig. 3. Symbols for various oxygens.

\section{IV硼酸ナトリウムガラスにおける 諸種の酸素のイオン屈折}

急冷あるいは徐冷された眮酸ナトリウムガラス中に 特ける $\mathrm{xy}_{4}$ 群及び諸種の酸素の數の増減は第 4 表の. 樣になり，この表から諸種の酸素のイオン屈折が次の 樣に求められる。

\section{策 4 表 諸種の酸素の數}

\begin{tabular}{|c|c|c|c|c|c|}
\hline \multirow{2}{*}{ 熱處理 } & \multirow{2}{*}{$\underset{\mathrm{u}}{\mathrm{Na}_{3} \mathrm{O} \text { 分子率 }}$} & \multicolumn{4}{|c|}{ 數 (比較值) } \\
\hline & & $x y_{4}$ & $\mathrm{O}^{B I V}$ & $\mathrm{ONa}^{\mathrm{Na}}$ & $\mathrm{O}^{\mathrm{BIII}}$ \\
\hline & $c-0.167$ & $2 \mathrm{u}$ & $8 \mathrm{u}$ & 0 & $3-10 u$ \\
\hline & 0.167 以上 & $2 / 5(1-u)$ & $8 / 5(1-u)$ & $2 / 5(6 \mathrm{u}-1)$ & $1 / 5(9-14 u)$ \\
\hline 急冷 & 全 域 & 0 & 0 & $2 \mathrm{u}$ & $3-4 u$ \\
\hline
\end{tabular}

と定義する。この式によつて次の $\mathrm{R}_{\mathrm{ONa}}$ ，OBIII の值が 得られる。 酸素及び陽イオンのイオン屈折とする。このうち $\mathrm{R}_{\mathrm{B}}$ 文び $\mathrm{R}_{\mathrm{Na}}$ は近似的に常數と考えることが出來, Kordes ${ }^{(9)}$ によつて與えられた次の值を用いる。

$$
\mathrm{R}_{\mathrm{Na}+}=0.442, \mathrm{R}_{\mathrm{B} 3+}=0.006
$$

1. 徐冷されたガラス 徐冷されたガラスでは $\mathrm{R}_{\mathrm{g}}$ 對 $\mathrm{u}$ 曲線は $\mathrm{u}=0.05$ から約 0.17 まではほとんど值 線でここから曲線は上に向つて曲り始める。この直 線部分に抬いては $\mathrm{R}_{\mathrm{OBIII}}$ 及び $\mathrm{R}_{\mathrm{OBIV}}$ の值は一定で なければならぬ。分子屈折の加算性により，

$$
\mathrm{R}_{\mathrm{g}}=2 \mathrm{uR} \mathrm{R}_{\mathrm{Na}}+2(1-\mathrm{u}) \mathrm{R}_{\mathrm{B}}+8 \mathrm{u} \mathrm{R}_{\mathrm{OBIV}}
$$$$
+(3-10 u) R_{0 B I I I}
$$

であるからこの $\mathrm{R}_{\mathrm{OBIII}}$ 及び $\mathrm{R}_{\mathrm{OBIV}}$ の值は次の樣に なる。

$R_{\mathrm{OBIII}}=3.577, \quad \mathrm{R}_{\mathrm{OBIV}}=3.313$

$\mathrm{u}$ が 0.167 以上になるともはや $\mathrm{xy}_{4}$ 群は新しく形成 されないで $\mathrm{R}_{\mathrm{g}}$ は

$$
\begin{aligned}
\mathrm{R}_{\mathrm{g}}=2 \mathrm{uR}_{\mathrm{Na}} & +2(1-\mathrm{u}) \mathrm{R}_{\mathrm{B}}+8 / 5(1-\mathrm{u}) \mathrm{R}_{\mathrm{OBIV}} \\
& +2 / 5(6 \mathrm{u}-1) \mathrm{R}_{\mathrm{ONa}}+1 / 5(9-14 \mathrm{u}) \mathrm{R}_{\mathrm{OBIII}}
\end{aligned}
$$

となる。この場合 $\mathrm{OBIV}^{\mathrm{BIV}} \mathrm{xy}_{4}$ 群の中心部にあるため 外部の Naイオンの影響をらけることが少く，そのイ オン屈折は $\mathbf{u}>0.167$ に执いて子 $\mathrm{u}<0.167$ の場合と 同じで 3.313 あると考えることができる。從つて $\mathrm{R}_{\mathrm{g}}$ 對 $\mathrm{u}$ 曲線が $\mathrm{u}$ が 0.167 を越えると曲るのは主 として $\mathrm{R}_{\mathrm{ONa}}$ が $\mathrm{u}$ と共に變化するからであらう。こ の場合新しく加えられた Naイオンはそれをとり圍も 酸素のちち特に一つの不飽和酸素に強くつながつてい ると考えられるから，われわれは $\mathrm{R}_{\mathrm{O}} \mathrm{BIII}$ もまた一定 で 3.577 であるとすることができ，この樣にして（3） 式から次の $R_{0 N a}$ の值が得られる。

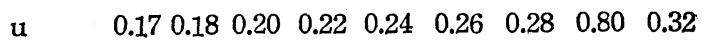

$\begin{array}{llllll}\mathrm{R}_{\mathrm{ONa}} & 1.9_{44} & 2.8_{21} & 3.09_{3} & 3.23_{1} & 3.3453 .4773 .6283 .7693 .911\end{array}$ ここに $\mathrm{R}_{\mathrm{ONa}}$ が $\mathrm{u}$ が 0.167 から増加するに從つて小 さい值から大きな值に變ることは注目すべきことであ る。

上の場合に揖いて，もし $\mathrm{R}_{\mathrm{OBIII}}$ む $\mathrm{R}_{\mathrm{ONa}}$ と共に變 化すると考えると

$$
R_{\mathrm{g}}=2 u R_{\mathrm{Na}}+2(1-\mathrm{u}) \mathrm{R}_{\mathrm{B}}+8 / 5(1-\mathrm{u}) \mathrm{R}_{\mathrm{OBIV}}
$$
$+1 / 5(7-2 u) R_{0 N a}$ OBIrI $\cdots(4)$ となる。但し $\mathrm{R}_{\mathrm{ONa}}$, OBIII は (ONaの數) $\mathrm{R}_{\mathrm{ONa}}+\left(\mathrm{O}^{\mathrm{BIII}}\right.$ の數) $\mathrm{R}_{\mathrm{OBIII}}$
$\equiv\left(\mathrm{O}^{\mathrm{Na}}\right.$ の數$+\mathrm{O}^{\mathrm{BIII}}$ の數 $) \mathrm{R}_{\mathrm{ONa}}$, OBIII
$\mathrm{R}_{\mathrm{ONa}}, \quad 3.5_{64} 3.5_{55} 3.54_{4} 3.53_{9} 3.5423 .5563 .5843 .6213 .667$ OBIII

實際に扔いては $\mathrm{u}$ の増加と共に $\mathrm{R}_{\mathrm{OBIII}}$ もある程 度變化すると考劣られるから $\mathrm{R}_{\mathrm{ONa}}$ 及び $\mathrm{R}_{\mathrm{OBIII}}$ の 值は上の三つの場合の中間にもるのであろら。

上記の $\mathrm{R}_{\mathrm{ONa}}$ の特異な值は第 1 表及び第 2 圖に示 した實測值から導かれたものであつて，圖に执いても し $\mathrm{R}_{\mathrm{g}}$ が曲線 $\mathrm{AB}$ 上になく直線 $\mathrm{AB}$ に沿つて變ると すれば $\mathrm{R}_{\mathrm{ONa}}$ の值は一定で $\mathrm{R}_{\mathrm{OBIII}}$ 即ち 3.577 に等 
しくなる。しかし，この附近の實測值は充分に多くは ないけれどる確かに直線 $A B$ より下にあると見られ るから,この $\mathrm{R}_{\mathrm{ONa}}$ の變化は比重及び屈折率の測定 誤差に基くるのと考えることはできない。

上の計算に用いた比重及び屈折率の值は常温に淤す る測定值である。からる温度に招いては前述の”樣に $\mathrm{Na}$ イオンの可動性は小さくなるために $\mathrm{BO}_{4}$ 四面體 の4 ケの酸素中 $\mathrm{Na}$ イオンの反對側の1ケは，岁る いは Na イオンの影響をらけていないか子知れない。 もしそらであるならばかつる酸素は O $\mathrm{O} I I I$ と同じ狀 態にあると考えられるから $\mathfrak{u}<0.167$ に對し

$\mathrm{R}_{\mathrm{g}}=2 \mathrm{u} \mathrm{R}_{\mathrm{Na}}+2(1-\mathrm{u}) \mathrm{R}_{\mathrm{B}}+6 \mathrm{u} \mathrm{R}_{\mathrm{OBIV}}+(3-8 \mathrm{u}) \mathrm{R}_{\mathrm{OBIII}}$

なる關係がありこれから

$\mathrm{R}_{\mathrm{OBIII}}=3.577, \mathrm{R}_{\mathrm{OBIV}}=3.225$

となり，u>0.167 では

$$
\begin{aligned}
\mathrm{R}_{\mathrm{g}} & =2 \mathrm{u} \mathrm{R}_{\mathrm{Na}}+2(1-\mathrm{u}) \mathrm{R}_{\mathrm{B}}+6 / 5(1-\mathrm{u}) \mathrm{R}_{\mathrm{OBIV}} \\
& +2 / 5(6 \mathrm{u}-1) \mathrm{R}_{\mathrm{ONa}}+1 / 5(11-16 \mathrm{u}) \mathrm{R}_{\mathrm{OBIII}} \cdots \cdots \text { (7) }
\end{aligned}
$$

で,これから次の $R_{0 N a}$ の值が (3) の式の場合と同 で樣にして求められる。

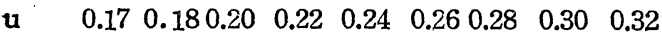
$\mathbf{R}_{\mathrm{ONa}} 1.3_{75} 2.6_{88} 2.02_{5} 3.19_{5} 3.3243 .4553 .5743 .7563 .897$ 即ちこの場合る ( 3 ) 式から得た $\mathrm{R}_{\mathrm{ONa}}$ の值と大差は ないのであつて，室温では $\mathrm{Na}$ イオンの可動性は減じ て $\mathrm{BO}_{4}$ 四面體の周りを動き廻ることはないと考えた 場合に扔いても $\mathrm{R}_{\mathrm{ONa}}$ の特異な變化は同樣に認めら れるのである。

2. 急冷されたガラス 急冷されたガラスでは $R_{g}$ 對 $\mathrm{u}$ 曲線は uが 0.05 以上の全域に對してほとんど直

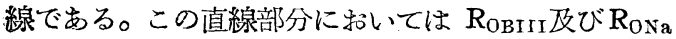
は一定であり，次の關係

$$
R_{\mathrm{g}}=2 \mathrm{uR}_{\mathrm{Na}}+2(1-\mathrm{u}) \mathrm{R}_{\mathrm{B}}+2 \mathrm{u} \mathrm{R}_{\mathrm{ONa}}+(3-4 \mathrm{u}) \mathrm{R}_{\mathrm{OBIII}}
$$

によつて $\mathrm{R}_{\mathrm{OBIII}}$ としては $3.453, \mathrm{R}_{\mathrm{ONa}}$ としては次の 值が得られる。

$$
\begin{array}{llllllll}
\mathbf{u} & 0.05 & 0.10 & 0.15 & 0.20 & 0.25 & 0.30 & 0.32 \\
\mathrm{R}_{\mathrm{ONa}} & 3.770 & 3.740 & 3.733 & 3.743 & 3.738 & 3.743 & 3.738 \\
\text { 平均值 } & \mathbf{3}
\end{array}
$$

3. $\mathbf{B}_{2} \mathrm{O}_{3}$ ガラスにおける酸素のイオン屈折 第2 表及び第 3 表に示した樣に $\mathrm{B}_{2} \mathrm{O}_{3}$ ガラスの分子属折は 徐冷及び急冷に對してそれぞれ 10.448 及び 10.528 である。これにKordesによつて與えられた $\mathrm{R}_{\mathrm{B}}=0.006$

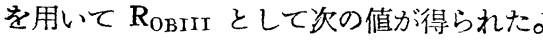

$\mathrm{R}_{\mathrm{OBIII}}$ 徐冷: 3.492 急冷: 3.505

上記の硼酸ナトリウムガラス中の諸種の酸素のインン 屈折の $\mathrm{Na}_{2} \mathrm{O}$ 含有量に伴弓變化を第 4 圖及び第 5 表

\begin{tabular}{|c|c|c|c|}
\hline $\begin{array}{l}\text { ガラスの種類 } \\
\mathrm{B}_{2} \mathrm{O}_{3} \\
\text { ガラ }\end{array}$ & & $\mathrm{Na}_{2} \mathrm{O}$ & $-\mathrm{B}_{2} \mathrm{O}_{3}$ ガラス \\
\hline 酸素の種類 OBIII & $\mathrm{OBIV}^{\mathrm{BIV}}$ & $\mathrm{O}^{\mathrm{BIII}}$ & $\mathrm{O}^{\mathrm{Na}}$ \\
\hline 徐冷 $\left\{\begin{array}{cc}u \quad u=0 \\
R \quad 3.492\end{array}\right.$ & $\begin{array}{l}\text { 全域 } \\
3.313\end{array}$ & $\begin{array}{l}\text { 全域 } \\
3.577\end{array}$ & $\begin{array}{l}\mathrm{u}=0.20 \cdots \mathrm{u}=0.32 \\
3.093 \cdots \cdots 3.911\end{array}$ \\
\hline 急冷 $\left\{\begin{array}{cc}u & u=0 \\
R & 3.505\end{array}\right.$ & - & $\begin{array}{l}\text { 全域 } \\
3.453\end{array}$ & $\begin{array}{l}\text { 全域 } \\
3.739\end{array}$ \\
\hline
\end{tabular}
に示す。

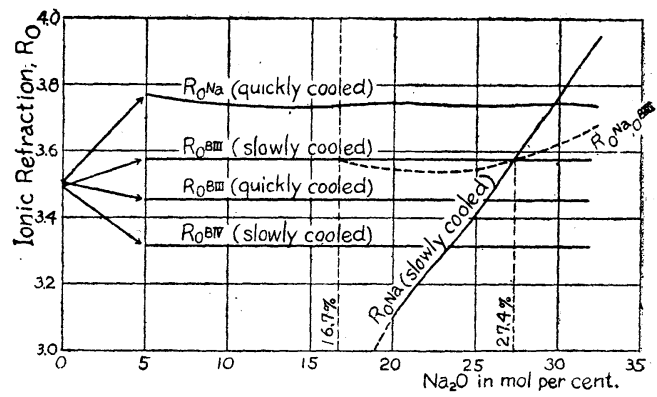

Fig. 4. Change of the ionic refraction of various oxygens with $\mathrm{Na}_{2} \mathrm{O}$ content.

策 5 表 諸種の酸素のイォン屈折

v. ガラス中の酸素のイオン屈折から見た磞酸 ナトリウムガラスの網目構造の安定性

いくつかの陽イオンにつながつている酸素のイオン 屈折は, 酸素原子の電子に及ぼす陽イオンの影響の大 きさを示すから，その值の減少は酸素と陽イオンとの 結合の強さが増すことを意味すると考えられる。この 樣な見方によつて上記の䃆酸ナトリウムガラスに稀け る諸種の酸素のイオン屈折の變化を論じてみよう。

1. $\mathrm{B}_{2} \mathrm{O}_{3}$ ガラス $\quad \mathrm{B}_{2} \mathrm{O}_{3} \quad$ ガラスは $\mathrm{B}$ 原子と OBIII 原子とから成る。 $\mathrm{R}_{\mathrm{OBIII}}$ の值は徐冷及び急冷 に對してそれぞれ 3.492 支び 3.505 であることは徐 。 冷した場合の方が急冷したものより B-O 結合が強い ことを示している。

2. 急冷された $\mathrm{Na}_{2} \mathrm{O}-\mathrm{B}_{2} \mathrm{O}_{3}$ 系ガラスこの種の ガラス中には $\mathrm{O}^{\mathrm{BIII}}$ と $\mathrm{O}^{\mathrm{Na}}$ との 2 種の酸素があり， それぞれのイォン属折は 3.453 と 3.739 である。こ れは急冷によつて高温度の狀態がそのま〉凍りついて いるすのと考光られ， $\mathrm{Na}-\mathrm{O}$ 結合は $\mathrm{B}-\mathrm{O}$ 結合よりも ずつと弱い。 $\mathrm{B}_{2} \mathrm{O}_{3}$ ガラスの $\mathrm{R}_{\mathrm{OBIII}}$ はこの二つの值 の中間である。

3. 徐冷された $\mathrm{Na}_{2} \mathrm{O}-\mathrm{B}_{2} \mathrm{O}_{3}$ 系ガラス, $\mathbf{u}<0.167$ の 
場合 この種のガラス中には $\mathrm{O}^{\mathrm{BIII}}$ と $\mathrm{O}^{\mathrm{BIV}}$ との 2 種の酸素があり，それぞれのイオン屈折は 3.577 と 3.313 で後者の方が著しく小さく, 前者は急冷ガラス

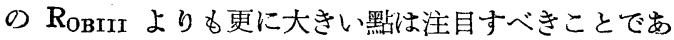
る。即ちこの場合に形成される $\mathrm{xy}_{4}$ 群の中心の $\mathrm{BO}_{4}$ の結合㥩しく強固であるが，それが形成されるため にその周圍の $\mathrm{BO}_{3}$ の結合は反對にゆるむこと, 即ち・ $\mathrm{BO}_{4}$ 四面體の周りの $\mathrm{BO}_{3}$ 三角形はその正常の狀態よ りも不安定な狀態となつていることを示している。な 特こ〉に注意すべきことは，この OBIII は OBIV 以 外の酸素の寸べてを意味してをり，單に $\mathrm{BO}_{4}$ 四面體 のすぐ周りの酸素だけでない。しかし $\mathrm{u}=0.05$ に拝 いては $\mathrm{xy}_{4}$ 群に屬する OBIII の數は $16 \mathrm{u}$ 即ち 0,8 であり $\mathrm{O}^{\mathrm{BIII}}$ の全數は 2.5 であるから $\mathrm{O}^{\mathrm{BIII}} 3$ ケ中 1 ケは $\mathrm{xy}_{4}$ 群に屬するものである。即ち例えば $\mathrm{xy}_{4}$ 群に第さない $\mathrm{BO}_{3}$ 三角形の 3 ケの酸素のうち ケは 必ず $\mathrm{xy}_{4}$ 群中の $\mathrm{BO}_{3}$ 三角形に屬するものである。 これは $\mathrm{u}=0.05$ のときであつて uが更に増せば $\mathrm{xy}_{4}$ 群は増加し，從つてそれに屬する OBIII の數もこれ よりずつと増加するわけであるから $\mathrm{u}=0.05$ から 0.167 の間に执いてはすべての $\mathrm{O}^{\mathrm{BIII}}$ は同樣に $\mathrm{BO}_{4}$ 四面體形成の影響をうけていると近似的に考えて差し 支えないであろう。

第 2 圖に示した樣に徐冷ガラスと急冷ガラスとの分 子屈折曲線が $u=0.13$ の近くで交つて持り，それ以 下では徐冷されたガラスの分子屈折の方が却つて大き くなつているのであるが，か〉る事實は唧珠酸ガラス ばかりでなくソーダ石灰ガラス，カリ石灰ガラス等の 分子屈折に扔いてす僅かではむるが認められることで あつて，徐冷によつて配位數等の變化によつてゆるい 結合も増加し得ることを意味している。

4 徐冷された $\mathrm{Na}_{2} \mathrm{O}-\mathrm{B}_{2} \mathrm{O}_{3}$ 系ガラス, $\mathbf{u}>0.167$ $\mathrm{xy}_{4}$ 群形成の限度 $\mathrm{u}=0.167$ 以上に $\mathrm{u}$ が増加すると 新しく加えられた $\mathrm{Na}$ イオンは $\mathrm{xy}_{4}$ 群の周邊部の

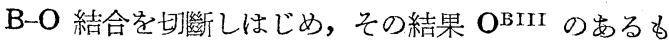
のが ONa に變るのであるが，上述の樣にこの場合新 しく生じる ONa のイオン屈折は最初著しく小さい值 をとる。このことは $\mathrm{xy}_{4}$ 群の周邊の $\mathrm{BO}_{3}$ 三角形分 $\mathrm{BO}_{4}$ 四面體の形成によつてかなり不安定となつてい るのが Na イオンによる B-O 結合の切斷によつて か〉る不安定がずつと小くなつてしまうことを意味し か〉る Na イオンは B-O 結合の切斷と同時に深い ポテンシャル孔の中に入ると考えられる。かつる Na イオンはその後に新しく加えられる Naイオンの樣に
自由でなくStevels ${ }^{10}$ 等の云ういわゆる “閉された (enclosed) Na イオン”に屬するものである。

この結果としてこの種のガラスに执いて u の值 が $0.167 か ら ~ 0.274$ 附近まで増加するに從つてその 網目構造の安定性は増加すると考えられる。

\section{VI. 硼珪酸ナトリウムガラスの場合}

1. $\mathrm{xy}_{4}$ 群が特に形成せられること $\quad \mathrm{Na}_{2} \mathrm{O}-\mathrm{B}_{2} \mathrm{O}$ $-\mathrm{SiO}_{2}$ 系ガラスに抏いて $\mathrm{SiO}_{4}$ 四面體を $z$ で表す と $\mathrm{xy}_{4}$ 群以外に $\mathrm{xy}_{3} \mathrm{z}, \mathrm{xy}_{2} \mathrm{z}_{2}, \mathrm{xyz}_{3}$ あるいは $\mathrm{xz}_{4}$ 等 の原子群もまた形成せられる筈である。即ち $\mathrm{BO}_{4}$ 四 面體と角頂を共有して $\mathrm{xy}_{4}$ 群の場合には 4 ケの $\mathrm{y}$ が つながつたがこの場合には 3 ケの $\mathrm{y}$ と 1 ケのz，2 ケ の $\mathrm{y}$ と 2 ケの $\mathrm{z}, 1$ ケの と 3 ケの $\mathrm{y}$, あるいは 4 ケ の $z$ がつながつてもよいと考えられる。しかし，上 の計算の結果からこの $\mathrm{BO}_{4}$ 四面體の形成によつて $\mathrm{xy}_{4}$ 群に扔ける $\mathrm{x}$ の周りの $\mathrm{y}$ はかなり不安定な狀態 になることがわかつたのであるが，この樣な不安定性 は $\mathrm{BO}_{4}$ 四面體の周りに平面的構造を有する $\mathrm{BO}_{3}$ 三 角形がつながる場合に比し立體的構造を有する $\mathrm{SiO}_{4}$ がつながる場合の方がはなはだしいことは充分想像で きるのであつて，か〉る理由から硯珪酸ガラスに拈け る原子群の形成は $\mathrm{xy}_{4}, \mathrm{xy}_{3} \mathrm{z}, \mathrm{xy}_{2} z_{2}, \mathrm{xyz}_{3}, \mathrm{xz}_{4}$ の順 序で困難になると考えられる。そして更にこの種のガ ラスに颃いて起りや寸い分離の現象から考えて, $\mathrm{xy}_{4}$ 群以外の原子群は形成が困難であると思われる。即ち この系のガラスに抬いて主として形成せられるのは $\mathrm{xy}_{4}$ 群であろら。そしてその結果として硯酸ナトリゥ ムガラスに揖いて見出される $\mathrm{xy}_{4}$ 群の性質は矹珠酸 ナトリウムガラスに执いても認められる筈である。

2. $\mathrm{Na}_{2} \mathrm{O}-\mathrm{B}_{2} \mathrm{O}_{3}-\mathrm{SiO}_{2}$ 三 元圖におけるガラスの熱膨 脹係數極小曲線及び轉移溫度極大曲線の位置 $\quad \mathrm{Na}_{2} \mathrm{O}$ $-\mathrm{B}_{2} \mathrm{O}_{3}-\mathrm{SiO}_{2}$ 三元圖に扔けるガラスの熱膨脹係數極小 曲線及び轉移温度極大曲線の位置は第 5 圖中 $\mathrm{C}^{\prime} \mathrm{D}$ 及 び SHG で示す。前者は Gooding 及び Turner(2)の 值から得たもので，後者は English 及びTurner(11)， English(12), Gehlhoff 及び Thomas(13), Cousen 友 び Turner(14), Gooding 及び Turner(2)及び山本(15) のデータから求めた。後者については上記の人々によ つて轉移温度，なまし温度，むるいは低温に打ける粘 度がこの三元圖上のいくつかの直線に沿つて與えら视 てをり，また山本氏は $50 \mathrm{wt} \% \mathrm{SiO}_{2}$ 以上の部分に拉 いて轉移温度の等高線を決定したが，これらのデータ は第 5 圖の SHG 曲線を定める上に非常によく一致し。 
ている。從つてこの SHG 曲線は低温度に执ける粘度 極大の位置を表すものと考兄られる。Gは $2 \mathrm{Na}_{2} \mathrm{O}$ ・ $5 \mathrm{~B}_{2} \mathrm{O}_{3}$ に相當し Gooding 攻び Turner の定めた點 である。

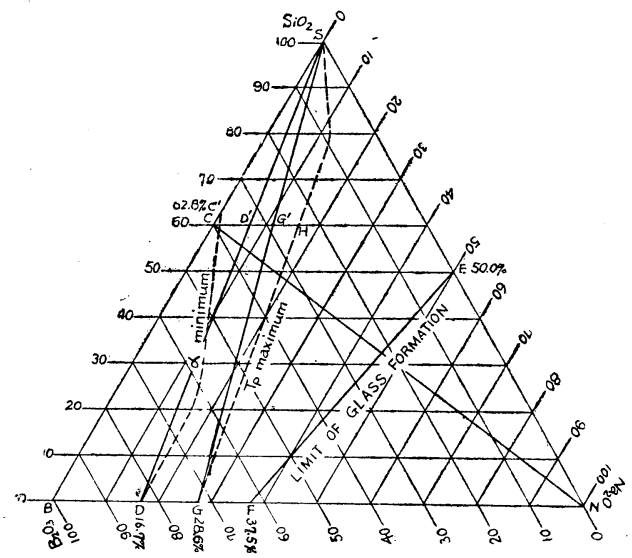

Fig. 5. Curves of maximum transition temperature $\left(T_{p}\right)$ and minium expansion coefficient $(\alpha)$ in the ternary system $\mathrm{Na}_{2} \mathrm{O}-\mathrm{B}_{2} \mathrm{O}_{3}-\mathrm{SiO}_{2}$. Composition in mol per cent.

上記の考察に基き 1 ケの $\mathrm{xy}_{4}$ 群に對して1 1 ケの $\mathrm{Na}$ イオンが閉された Na イオンとなり得ると假定するこ とができる。即ち $\mathrm{xy}_{4}$ 群の組成は $\mathrm{Na}_{2} \mathrm{O} \cdot 5 \mathrm{~B}_{2} \mathrm{O}_{3}$ であ るから自由な $\mathrm{Na}$ イオンは $2 \mathrm{Na}_{2} \mathrm{O} \cdot 5 \mathrm{~B}_{2} \mathrm{O}_{3}$ から生じ 始めると考兄られる。の組成に對する $\mathrm{u}$ の值は 0.286 で第 4 圖及び V-4 に述べた實驗值から導いた uの值 0.274 とよく一致する。

これからこの三元圖における轉移温度極大の點は直 線 SG に沿万と豫想されるのであるが，實際は曲線 SHGに沿つて起る。これは Si-O 網目においても閉さ れた Na イオンが存在することを示するのであろら。 即ち $\mathrm{Si}-\mathrm{O}$ 結合に生じている無理が $\mathrm{Na}$ イオンがその 結合を切斷することによつてゆるめられ，それと同時 にその Na イオンが深いポテンシャル孔の中に捕えら れると考えられるのである。

Stevels ${ }^{10}$ はか〉る閉された Na イオンを假定する ことによつて單にガラスをなますことだけによつてそ の力率が小さくなり, 電氣抵抗が増すこと, 及び理酸 ガラス中の $\mathrm{K}_{2} \mathrm{O}$ を $\mathrm{Na}_{2} \mathrm{O}$ て置換するときに起る力 率及び電氣抵抗の變化を説明したのであるが， $\mathrm{SiO}_{2}$ ガラスの性質とアルカリ $\mathrm{SiO}_{2}$ ガラスの性質のアルカ リ含有量零まで外挿して求めた值との間に認められる 食い違いも，からる閉された $\mathrm{Na}$ イオンによるものと
考えられる。

3. $\mathrm{Na}_{2} \mathrm{O}-\mathrm{B}_{2} \mathrm{O}_{3}-\mathrm{SiO}_{2}$ 三元圖における製品用嶰珪酸 ガラスの位置 $\mathrm{SiO}_{2}$ 含有量の多いガラスではその 愹融及び清澄温度を低くするため, ある程度の $\mathrm{Na}_{2} \mathrm{O}$ の添加は必要であるが, その樣な最低限度の $\mathrm{Na}_{2} \mathrm{O}$ で もガラスの性質を惡くする傾向がある。しかし，もし ガラスの冷却過程に扔いで $\mathrm{Na}$ イオンを閉されたイ オンとすることが出來るならば， $\mathrm{Na}_{2} \mathrm{O}$ のこの樣な好 ましくない影響はずつと小さくすることができる。實 際問題として $\mathrm{SiO}_{2}$ 含有量はあまり少くできないこと を考虑に入れて，上記の考え方からこの三元圖に抢け る優良なガラスの領域として SD'G'HS をとること ができるであろら。商品用の嗍珃酸ガラスは $\mathrm{Na}_{2} \mathrm{O}$,

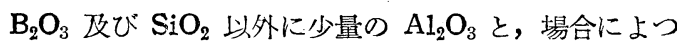
ては數\%の $\mathrm{K}_{2} \mathrm{O}$ 及び $\mathrm{RO}$ 型の酸化物を含有する。 ガラスガ熔融狀態から冷却されるとき比較的高温度に 扔いては $\mathrm{SiO}_{4}$ 四面體と $\mathrm{BO}_{3}$ 三角形とが網目構造を 形成している。次に修飾酸化物の1ヶの $\mathrm{M}^{+}$イオン (あるいは $1 / \mathrm{n}$ ケの $\mathrm{M}^{\mathrm{n}+}$ イオン) を伴つた $\mathrm{AlO}_{4}$ 四 面體が網目構造に加わる。更に温度が下つて粘度が $1.5 \times 10^{12}$ poises 附近になると殘りの修飾酸化物の 1 ケの $\mathrm{M}^{+}$イオン (あるいは $1 / \mathrm{n}$ ケの $\mathrm{M}^{\mathrm{n}+}$ イオン) を伴つた $\mathrm{xy}_{4}$ 群が網目構造中に形成される。この樣な 考方方に基いて計算すると商品用硼珠酸ガラスのほと んどすべてのものはこの領域中に含まれることがわ る。そのうち $\mathrm{SD}^{\prime}$ 線に近いガラスはガラス細工が極 めてしやすく, その $\mathrm{SiO}_{2}$ 含有量が $80 \%$ に近い場合 にはその化學的耐久性も充分大きい。また $\mathrm{SH}$ 線に 近いガラスは化學的耐久性が大きく且つ高温度に耐兄 得ることが見出される。

\section{VlI. 總 括}

著者は前に $\mathrm{B}_{2} \mathrm{O}_{3}$ を含有するガラス中では修飾酸化 物の陽イオンが互に近接し難いことに基き, 粘度 $1.5 \times 10^{12}$ poises 即ちガラスの屈伏 點に近い温度で $\mathrm{xy}_{4}$ 群と名づけられる原子集團か形成せられることに 關していろいろ述べたが，本論交に扔いては既に注意 深く測定されている硼酸ナトリウムガラスの比重と屈 折率の值からこの $\mathrm{xy}_{4}$ 群の形成を細かく檢討し, そ の結果嗍珠酸ガラスの構造及び性質を更に明かにする ことができた。

まづガラス中に郝ける $\mathrm{xy}_{4}$ 群形成の過程を考光， 熱膨脹係數極小の組成から $\mathrm{xy}_{4}$ 群に抢ける $\mathrm{BO}_{4}$ 四面 體の 4 ケの不飽和酸素がその四面體に屬している1 
の Naイオンによつて均等に中和されていることを推 論した。次に $\mathrm{xy}_{4}$ 群が徐冷されたガラス中だけに形 成せられると考え, 硯酸ナトリウムガラス中に拈ける 諸種の酸素のイオン屈折を求めた。計算に必要な比重 及び屈折率は徐冷ガラスに對しては Gooding 及び Turner, Wulff 及び Majumdar, Morey 及び Merwin, Tillotson, Bedson 及び Williams, 及び Stevels の值, 急冷ガラスに對してはWulff 文び Majumdar の值を用いた。その結果は次表の通りで おる。表中の O $\mathrm{O} I \mathrm{BI}, \mathrm{O}^{\mathrm{BIV}}$ 及び $\mathrm{O}^{\mathrm{Na}}$ はそれぞれ2 ケの $\mathrm{BO}_{3}$ 三角形， 1 ケの $\mathrm{BO}_{3}$ 三角形と 1 ケの $\mathrm{BO}_{4}$ 四面體, 1 ケの $\mathrm{BO}_{3}$ 三侜形と 1 ケの $\mathrm{Na}$ イオンを つなぐ酸素であつて, 計算に當つて, $\mathrm{B}, \mathrm{Na}$ 及び OBIV のイオン属折は u の全域に對して不變である と假定した。

$$
\begin{aligned}
& \text { ガラスの } \mathrm{B}_{2} \mathrm{O}_{3} \\
& \text { 類 ガラス }
\end{aligned} \mathrm{Na}_{2} \mathrm{O}-\mathrm{B}_{2} \mathrm{O}_{3} \text { ガラス }
$$

酸素の種類 OBIII $\mathrm{OBIV}^{\mathrm{BBIII}} \mathrm{O}^{\mathrm{Ba}}$

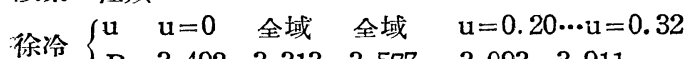

徐冷 $\left\{\begin{array}{lllll}\mathrm{u} & \mathrm{u}=0 & \text { 全域 } & \text { 全域 } & \mathrm{u}=0.20 \cdots \mathrm{u}=0.32 \\ \mathrm{R} & 3.492 & 3.313 & 3.577 & 3.093 \cdots 3.911\end{array}\right.$

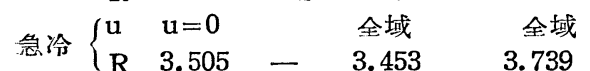

この表から $\mathrm{xy}_{4}$ 群の中心部にある $\mathrm{BO}_{4}$ 四面體の

B-O 結合は非常に強く,この四面體の形成によつて その周圍の $\mathrm{BO}_{3}$ 三盾形の $\mathrm{B}-\mathrm{O}$ 結合はりるくなり, これらの $\mathrm{BO}_{3}$ 三角形はその正常の狀態よりも不安定 となることが了解される。

$\mathrm{Na}_{2} \mathrm{O}-\mathrm{B}_{2} \mathrm{O}_{3}-\mathrm{SiO}_{2}$ の三元系ガラスに拀いては $\mathrm{xy}_{4}$ 群以外に $\mathrm{xy}_{3} \mathrm{z}, \mathrm{xy}_{2} \mathrm{z}_{2}, \mathrm{xyz}_{3}$ あるいは $\mathrm{xz}_{4}$ 等の原子 群も形成されると考えられる。但し, $z$ は $\mathrm{SiO}_{4}$ 四面 體を表し $\mathrm{xy}_{4}$ 群の 1 乃至 4 ケの $\mathrm{y}$ に置換する場合を 示す。しかし, 二次元的構造の $\mathrm{y}$ が三次元的構造の $z$ に代ると上記の不安定性が増すこと, 及びこの種の ガラスが 2 相に分離しやすい傾向を有することからこ れらのガラス中では $\mathrm{xy}_{4}$ 群以外の上記原子群は形成 され難いと考えられる。

$\mathrm{u}$ の值が 0.167 を越えると $\mathrm{Na}$ イオンは $\mathrm{xy}_{4}$ 群 の周りの B-O 結合を切り始め, その結果 $\mathrm{BO}_{4}$ 四面 體の周りの $\mathrm{BO}_{2}$ 三角形の不安定は幾分減少する。そ してこれらの Na イォンは B-O 結合を切断すると 同時に深いポテンシャル孔の中に落ちることが想像さ れる。か〉る Naイオンはその後から加えられる $\mathrm{Na}$

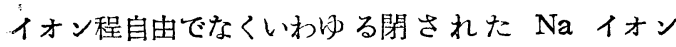

であると考えることがでる。1ケの $\mathrm{xy}_{4}$ 群に對し て1ケの Na イオンがこの閉された Na イオンとな り得ると假定すると自由な $\mathrm{Na}$ イオンは $2 \mathrm{Na}_{2} \mathrm{O} \cdot 5 \mathrm{~B}_{2} \mathrm{O}_{3}$ の組成, 即ち $\mathrm{u}=0.286$ から生じ始めるわけであるが この值は酸素のイオン屈折から導いたか〉る u の值 と極めてよく一致する。 $\mathrm{Si}-\mathrm{O}$ 網目構造に招いてもこ の樣な閉された $\mathrm{Na}$ イオンが在ると考えることに よつて $\mathrm{Na}_{2} \mathrm{O}-\mathrm{B}_{2} \mathrm{O}_{3}-\mathrm{SiO}_{2}$ の三元圖に抬ける轉移温度 極大曲線の位置がよく説明できる。ガラスを熔融狀態 から冷却する際にその Naイオンを閉された Naイオ ンに變えることが出來れば $\mathrm{Na}_{2} \mathrm{O}$ がガラスの性質に 及ぼす好ましくない影響をなくすことが出來るのであ るが，ほとんどすべての商品用硯珪酸ガラスはか〉る 條件を充す組成範園に入つていることがわかる。

$$
\text { 文献 }
$$

（1）安部俊夫, 窯協, 昭 25,58, [654], 421, 昭 $26,59,[658], 150$.

(2) E. J. Gooding and W. E. S. Turner, J. Soc. Glass Techn., 1934, 18, 32.

(3) P. Wulff and S. K. Majumdar, $Z$. Ph.sik. Chem. B, 1936, 31, 319.

(4) G. W. Morey and H. E. Merwin, J. Am. Chem. Soc., 1936, 58, 2248.

(5) E.W. Tillotson, J.Am. Cer. Soc., 1918, 1, 76.

(6) P. P. Bedson and C. Williams, "Properties of Glass”, 372, G. W. Morey 1938.

(7) J. M. Stevels, "Progress in the Theory of the Physical Properties of Glass", 96, 1948.

(8) J. Biscoe and B. E. Warren, J. Am. Cer. Soc., 1938, 21, 287.

(9) E. Kordes, Z. Physit. Chem. B, 1939, 43, 213; 1939, 44, 249.

(10) J. M. Stevels, "Progress in the Theory of the Physical Properties of Glass",80, 1948.

(11) S. English and W. E. S. Turner, J. Soc. Glass Techn., 1923, 7, 73.

(12) S. English, J. Soc. Glass Techn., 1924, 8, 205.

(13) G. Gehlhoff and M. Thomas, Z. Techn. Phys. 1926,7, 260.

(14) A. Cousen and W. E. S. Turner, J. Soc. Glass Techn., 1928, 12, 169.

(15）山本準之助, 筀協, 昭26，59，10月

(7/28/51 無付) 